\title{
eNOS Activation Induced by a Polyphenol-Rich Grape Skin Extract in Porcine Coronary Arteries
}

\author{
Socorro Vanesca Frota Madeira ${ }^{a}$ b Cyril Auger ${ }^{a}$ Eric Anselm ${ }^{a}$ \\ Marta Chataigneau $^{a}$ Thierry Chataigneau ${ }^{a}$ Roberto Soares de Mourab \\ Valérie B. Schini-Kerth ${ }^{a}$ \\ a UMR CNRS 7175, Pharmacologie et Physico-Chimie, Faculté de Pharmacie, Université Louis Pasteur, Illkirch, France; \\ ${ }^{b}$ Department of Pharmacology, IBRAG-CB State University of Rio de Janeiro, Rio de Janeiro, Brazil
}

\section{Key Words}

Grape skin extract $\cdot$ Phosphoinositide 3-kinase $\cdot$ Nitric

oxide $\cdot$ Endothelium $\cdot$ Porcine coronary artery

\begin{abstract}
Background/Aims: Drinking red wine is associated with a decreased mortality from coronary heart diseases. This study examined whether polyphenols contained in a grape skin extract (GSE) triggered the endothelial formation of nitric oxide (NO) and investigated the underlying mechanism. Methods: Vascular reactivity was assessed in organ chambers using porcine coronary artery rings in the presence of indomethacin (a cyclooxygenase inhibitor) and charybdotoxin plus apamin (inhibitors of endothelium-derived hyperpolarizing factor-mediated responses). The phosphorylation level of Src, Akt and endothelial NO synthase (eNOS) were assessed by Western blot analysis, and the formation of reactive oxygen species (ROS) was investigated using dihydroethidine and dichlorodihydrofluorescein. Results: GSE-induced endothelium-dependent relaxations were abolished by $\mathrm{N}^{\mathrm{G}}$-nitro-L-arginine (an eNOS inhibitor) and ODQ (a solu-
\end{abstract}

ble guanylyl cyclase inhibitor), and they were reduced by MnTMPyP, polyethyleneglycol catalase, PP2 (an inhibitor of Src kinase) and wortmannin (an inhibitor of phosphoinositide 3-kinase). GSE caused phosphorylation of Src, which was prevented by MnTMPyP. It also caused phosphorylation of Akt and eNOS, which were prevented by MnTMPyP, polyethyleneglycol catalase, PP2, wortmannin and LY294002. GSE elicited the formation of ROS in native and cultured endothelial cells, which was prevented by MnTMPyP. Conclusions: GSE causes endothelium-dependent NO-mediated relaxations of coronary arteries. This effect involves the intracellular formation of ROS in endothelial cells leading to the Src kinase/phosphoinositide 3-kinase/Akt-dependent phosphorylation of eNOS.

Copyright $\odot 2009$ S. Karger AG, Basel

\section{Introduction}

Epidemiological studies have indicated an inverse correlation between red wine consumption and the risk of cardiovascular diseases [1-3]. The protective effect of red

\section{KARGER}

Fax +41613061234 E-Mail karger@karger.ch www.karger.com
(C) 2009 S. Karger AG, Basel

1018-1172/09/0465-0406\$26.00/0

Accessible online at:

www.karger.com/jvr
Dr. Valérie B. Schini-Kerth

UMR CNRS 7175, Département Pharmacologie et Physico-Chimie

Université Louis Pasteur, 74, route du Rhin, FR-67401 Illkirch (France)

Tel. +33 39024 4127, Fax +33 390244313

E-Mail valerie.schini-kerth@pharma.u-strasbg.fr 
wine on the cardiovascular system is due, at least in part, to the polyphenolic component [4]. Indeed, numerous studies indicate that both acute and chronic administration of various preparations from polyphenol-rich foods or beverages has a beneficial effect on hemodynamic parameters in patients and animals. For instance, chronic intake of $100 \mathrm{~g}$ of dark polyphenol-rich chocolate for 14 days decreased both diastolic and systolic blood pressure within 10 days in patients with mild isolated systolic hypertension [5]. In patients with at least 1 cardiovascular risk factor (coronary artery disease, hypertension, hyperlipidemia, diabetes or smoking), ingestion of $100 \mathrm{ml}$ of a cocoa drink containing high amounts of flavonoids increased endothelium-dependent vasodilation, an effect associated with an increased plasma nitric oxide (NO) pool [6]. Furthermore, it has been observed that in healthy humans, regular intake of a flavonoid-rich cocoa for 4 days induced a prominent peripheral vasodilation via activation of the NO pathway [7]. Endothelium-dependent flow-mediated vasodilation is also improved after acute intake of $500 \mathrm{ml}$ of red wine with or without alcohol in healthy men, as determined by ultrasonography of the brachial artery [8]. In addition, experimental evidence indicates that red wine polyphenols can induce pronounced endothelium-dependent relaxations of isolated arteries through an increased formation of both $\mathrm{NO}$ and endothelium-derived hyperpolarizing factor (EDHF), 2 endothelial factors that play major roles in the control of vascular homeostasis [9-15].

Recently, we have shown that chronic intake of the polyphenols contained in an alcohol-free lyophilized Brazilian red wine or in an alcohol-free grape skin extract (GSE) from Vitis labrusca reduced systolic, mean and diastolic arterial pressure in several experimental models of hypertension $[16,17]$. Both types of extracts also caused endothelium-dependent vasodilation in the perfused rat mesenteric vascular bed by increasing the endothelial formation of both NO and EDHF [16-18]. The aim of the present study was to characterize the signaling pathway leading to the enhanced endothelial formation of $\mathrm{NO}$ in response to GSE using isolated coronary arteries and cultured coronary artery endothelial cells.

\section{Methods}

\section{Preparation of the GSE}

$V$. labrusca (Isabel variety) red grapes were obtained from selected vineyards located in the state of Rio Grande do Sul, Brazil. The grapes were washed in tap water and the skins were separated from the pulps. Approximately $100 \mathrm{~g}$ of skin were boiled in 400 $\mathrm{ml}$ of distilled water for $5 \mathrm{~min}$ and then minced. $400 \mathrm{ml}$ of ethanol was added to the decoction, shaken for $4 \mathrm{~h}$ and kept in dark bottles inside a refrigerator $\left(4^{\circ} \mathrm{C}\right)$ for 20 days. The hydroalcoholic extract of $V$. labrusca skins was filtered through Whatman No. 1 filter paper and the ethanol was evaporated under low pressure at $55^{\circ} \mathrm{C}$. The extract was lyophilized and frozen at $-20^{\circ} \mathrm{C}$ until the day of use. $100 \mathrm{~g}$ wet skins yield about $8.9 \mathrm{~g}$ of lyophilized extract. The concentration of polyphenols in lyophilized GSE was $55.5 \mathrm{mg} / \mathrm{g}$, as measured by analysis of total phenol by the Folin-Ciocalteu procedure [19].

\section{Vascular Reactivity Studies}

Left anterior descending porcine coronary arteries (obtained from the local slaughterhouse) were cleaned of connective tissue and cut into rings. Rings were suspended in organ baths containing oxygenated $\left(95 \% \mathrm{O}_{2}\right.$ and $\left.5 \% \mathrm{CO}_{2}\right)$ Krebs bicarbonate solution (in mM: $\mathrm{NaCl} 119, \mathrm{KCl} 4.7, \mathrm{KH}_{2} \mathrm{PO}_{4} 1.18, \mathrm{MgSO}_{4} 1.18, \mathrm{CaCl}_{2} 1.25$, $\mathrm{NaHCO}_{3} 25$, and D-glucose $11 ; \mathrm{pH} 7.4,37^{\circ} \mathrm{C}$ ) under a resting tension of $5 \mathrm{~g}$ for the determination of changes in isometric tension, as described previously [14]. Rings were constricted with U46619 before a concentration-relaxation curve to either GSE or bradykinin was constructed. All experiments (except as indicated) were performed in the presence of indomethacin, an inhibitor of cyclooxygenases, and the combination of charybdotoxin and apamin (both inhibitors of calcium-activated potassium channels) to rule out the formation of vasoactive prostanoids and EDHF, respectively. In some experiments, rings were incubated with a modulator for $30 \mathrm{~min}$ before addition of $\mathrm{U} 46619$.

\section{Culture of Coronary Artery Endothelial Cells}

Porcine coronary artery endothelial cells were isolated by collagenase treatment (type I, Worthington; $1 \mathrm{mg} / \mathrm{ml}$ for $12 \mathrm{~min}$ at $37^{\circ} \mathrm{C}$ ), and cultured as described previously [14]. All experiments were performed with confluent cultures of cells used at first or second passage. They were exposed to serum-free culture medi$\mathrm{um}$ in the presence of $0.1 \%$ bovine serum albumin for $6 \mathrm{~h}$ prior to treatment.

Determination of the Phosphorylation Level of Src, Akt and Endothelial NO Synthase

Total protein $(25 \mu \mathrm{g})$ was separated on SDS-polyacrylamide gels $(12 \%)$ at $70 \mathrm{~V}$ for $3.5 \mathrm{~h}$ and then transferred electrophoretically $(100 \mathrm{~V}$ for $2 \mathrm{~h}$ ) to polyvinylidine difluoride membranes (Amersham-Pharmacia Biotech, Piscataway, N.J., USA). Immunodetection was carried out using primary antibodies directed against either phosphorylated Src, phosphorylated endothelial NO synthase (eNOS) or phosphorylated Akt (Cell Signaling Technology, Beverly, Mass., USA). The immunoreactive bands were detected by enhanced chemiluminescence (Amersham Biosciences). Ponceau staining was performed to verify the quality of the transfer and equal amounts of proteins in each lane.

\section{Detection of Reactive Oxygen Species in Cultured and Native}

Endothelial Cells

The oxidative fluorescent dye dihydroethidine (DHE) was used to evaluate the production of reactive oxygen species (ROS) in cultured endothelial cells by use of a method described by Miller et al. [20]. DHE permeates freely into cells and in the presence of ROS is oxidized to ethidium bromide, which is trapped by intercalating with the DNA. Cultured coronary endothelial cells 


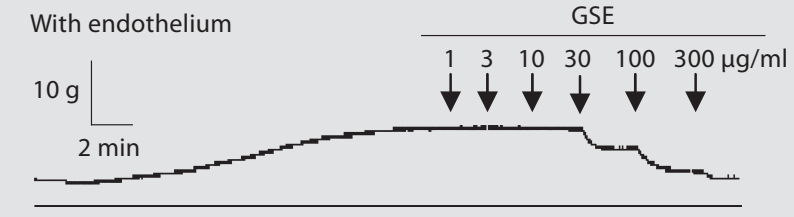

Without endothelium

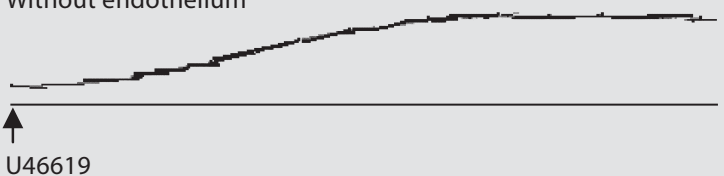

U46619

a

Fig. 1. a Original tracings showing endothelium-dependent relaxations to GSE in isolated porcine coronary arteries. b Effect of $\mathrm{N}^{\mathrm{G}}$-nitro-L-arginine (L-NA, $\left.100 \mu \mathrm{M}\right)$, apamin (100 nM) plus charybdotoxin $(100 \mathrm{nM})$, and the combination of L-NA and apamin plus charybdotoxin on GSE induced relaxation in coronary artery

were rinsed in PBS and incubated in Hanks' balanced salt solution containing DHE $(10 \mu \mathrm{M})$ in a light-protected humidified chamber at $37^{\circ} \mathrm{C}$. After $10 \mathrm{~min}$, cells were exposed to either solvent (ethanol $0.5 \%)$ or GSE. In some experiments, cells were exposed to Mn(III)tetrakis(1-methyl-4-pyridyl)porphyrin (MnTMPyP; 100 $\mu \mathrm{M})$ for $30 \mathrm{~min}$ before addition of GSE. Images were obtained with a Bio-Rad MRC-1024 laser scanning confocal microscope equipped with a krypton/argon laser. Laser settings were identical for acquisition of images from solvent and GSE-treated cells. Ethidium bromide was excited at $488 \mathrm{~nm}$ with an emission spectrum of $610 \mathrm{~nm}$. Fluorescence was detected with a 585-nm longpass filter.

The in situ formation of ROS was assessed in coronary artery sections using the redox-sensitive fluorescent probe 5-(and-6-)chloromethyl-2',7'-dichlorodihydrofluorescein diacetate (DCHF; Invitrogen ${ }^{\mathrm{TM}}$ ). Coronary artery rings were incubated in PBS for 30 $\mathrm{min}$ at $37^{\circ} \mathrm{C}$ in the absence or presence of a modulator before being embedded in Tissue-Tek OCT compound (Qaigen, Hilden, Germany), and frozen in liquid nitrogen. These unfixed frozen artery rings were cut into 25 - $\mu \mathrm{m}$ thick sections and placed on polylysinecoated plus glass slides. Artery sections were exposed to DCHF for $15 \mathrm{~min}$ at $37^{\circ} \mathrm{C}$ before the treatment with GSE in the absence or presence of the respective modulator. Thereafter, DCHF fluorescence was determined by confocal microscope (1024 MRC; BioRad, Hercules, Calif., USA) with a $\times 10$ epifluorescence objective (Nikon, Tokyo, Japan). After excitation at $488 \mathrm{~nm}$ with a krypton/ argon laser, the emission signal was recorded with a Zeiss 565-610 $\mathrm{nm}$ filter. Images were analyzed by the Confocal Assistant ${ }^{\mathrm{TM}}$ (CAS 40 version $4.02,1024 \times 728$ pixels, 32 bits per pixel).

Chemicals

$\mathrm{N}$-acetylcysteine, $\mathrm{N}^{\mathrm{G}}$-nitro-L-arginine (L-NA), $1 \mathrm{H}$-[1,2,4] oxadiazolo[4,3-a]quinoxalin-1-one (ODQ), apocynin, sulfaphenazol,

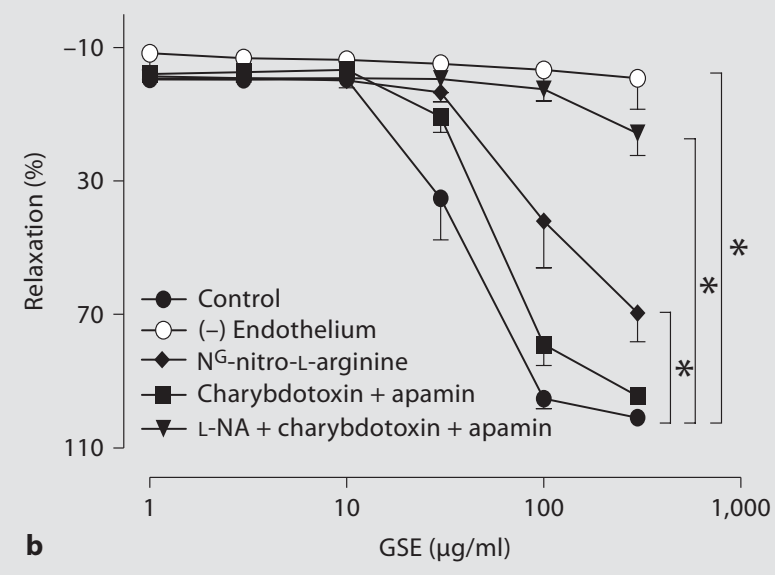

rings with endothelium. The effect of GSE in rings without endothelium is also shown. All experiments were performed in the presence of indomethacin $(10 \mu \mathrm{M})$. Results are shown as means \pm SEM of 6 different experiments. ${ }^{*} \mathrm{p}<0.05$ for inhibitory effect.

rotenone, allopurinol, apamin, charybdotoxin, indomethacin, bradykinin, superoxide dismutase, polyethylene-glycol- superoxide dismutase (PEG-superoxide dismutase), catalase, polyethylene-glycol-catalase (PEG-catalase) and DHE were obtained from Sigma (St. Louis, Mo., USA). 9,11-dideoxy-11 $\alpha$, $9 \alpha$-epoxymethano-prostaglandin F2 $\alpha$ (U46619) was purchased from Cayman Chemical (Ann Arbor, Mich., USA). Wortmannin, LY294002, PD98059, SB203580, L-JNKI, superoxide dismutase mimetic MnTMPyP were from Alexis Chemicals (Läufelfingen, Switzerland). 4-amino-5-(4-chlorophenyl)-7-( $t$-butyl) pyrazolo[3,4d]pyrimidine (PP2) was obtained from Calbiochem (San Diego, Calif., USA).

\section{Statistical Methods}

Values are expressed as means \pm SEM. Statistical evaluation was performed with Student's t test for paired data or ANOVA followed by Fisher's protected least significant difference test where appropriate. Values of $\mathrm{p}<0.05$ were considered statistically significant.

\section{Results}

\section{GSE Induces Endothelium-Dependent Relaxations in Isolated Coronary Arteries}

In the presence of indomethacin $(10 \mu \mathrm{M}), \mathrm{GSE}$ induced concentration-dependent relaxations in rings with endothelium starting at concentrations greater than $10 \mu \mathrm{g} / \mathrm{ml}$ and reaching a near maximal relaxation at $100 \mu \mathrm{g} / \mathrm{ml}$, whereas in rings without endothelium no such effect was observed (fig. 1a, b). Relaxations to GSE 


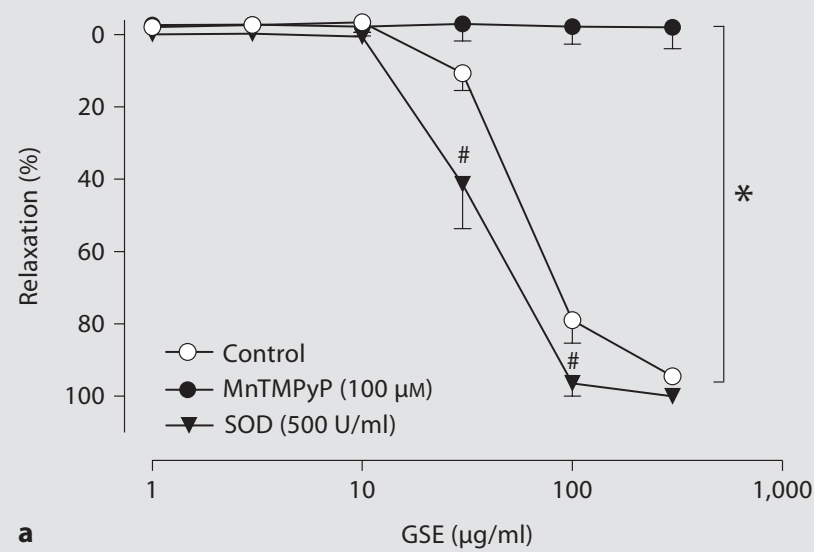

a

Fig. 2. Role of reactive oxygen species in endothelium-dependent $\mathrm{NO}$-mediated relaxations to GSE in intact coronary artery rings. Artery rings were incubated with either superoxide dismutase (SOD) or MnTMPyP (a) and either catalase or PEG-catalase (b) for $30 \mathrm{~min}$ before the addition of U46619. All experiments were

Fig. 3. Role of several enzymatic sources of ROS on endotheliumdependent NO-mediated relaxations to GSE in intact coronary artery rings. Artery rings with endothelium were incubated with an inhibitor of NADPH oxidase (apocynin) or of xanthine oxidase (allopurinol) or of cytochromes P450 (sulfaphenazol) or of the mitochondrial respiratory chain (rotenone) for $30 \mathrm{~min}$ before the addition of U46619. All experiments were performed in the presence of charybdotoxin $(100 \mathrm{nM})$, apamin $(100 \mathrm{nM})$ and indomethacin $(10 \mu \mathrm{M})$. Results are shown as the means \pm SEM of 5 different experiments.

were significantly reduced by L-NA, an inhibitor eNOS, minimally affected by charybdotoxin plus apamin, markedly decreased by the combination of L-NA with charybdotoxin plus apamin and by the combination of ODQ with charybdotoxin plus apamin (relaxations induced by $300 \mu \mathrm{g} / \mathrm{ml} \mathrm{GSE}$ were $97.0 \pm 8.7 \%$ and $1.8 \pm$ $1.7 \%$ in the absence and presence of ODQ $3 \mu \mathrm{M}, \mathrm{n}=4$ ). These findings indicate that GSE causes endotheliumdependent relaxations involving predominantly $\mathrm{NO}$ and also, to some extent, EDHF. To characterize the mechanisms involved in the endothelium-dependent NO-me-

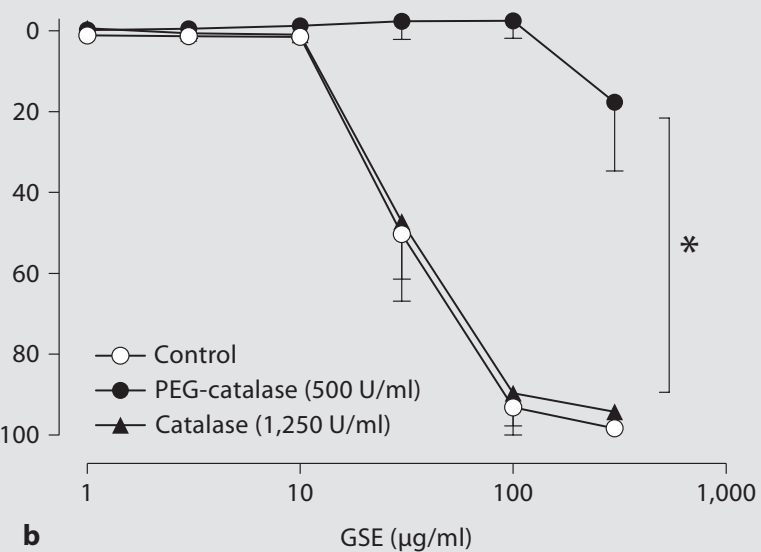

performed in the presence of charybdotoxin (100 nM), apamin $(100 \mathrm{nM})$ and indomethacin $(10 \mu \mathrm{M})$. Results are shown as the means \pm SEM of 6 different experiments. ${ }^{*} \mathrm{p}<0.05$ for inhibitory effect; ${ }^{*}=$ different from control $(\mathrm{p}<0.05)$.

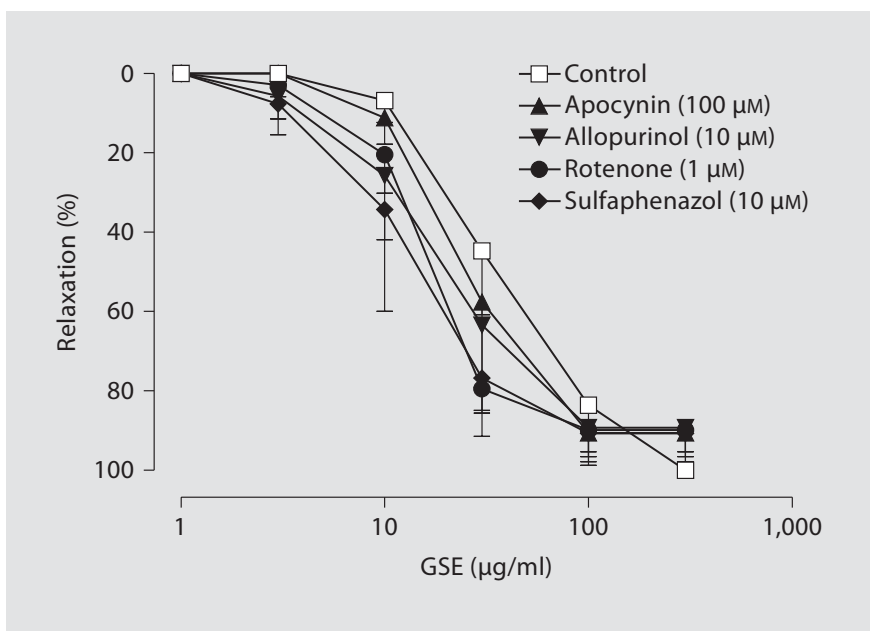

diated relaxation to GSE, all further experiments were performed in the presence of indomethacin and charybdotoxin plus apamin.

\section{Role of ROS in GSE-Induced NO-Mediated Relaxation}

Previous studies have indicated that red wine polyphenols are able to induce NO- and EDHF-mediated relaxations and hyperpolarization in porcine coronary arteries that are strictly dependent upon the intracellular formation of superoxide anions in endothelial cells [1214]. Therefore, experiments were performed to determine 

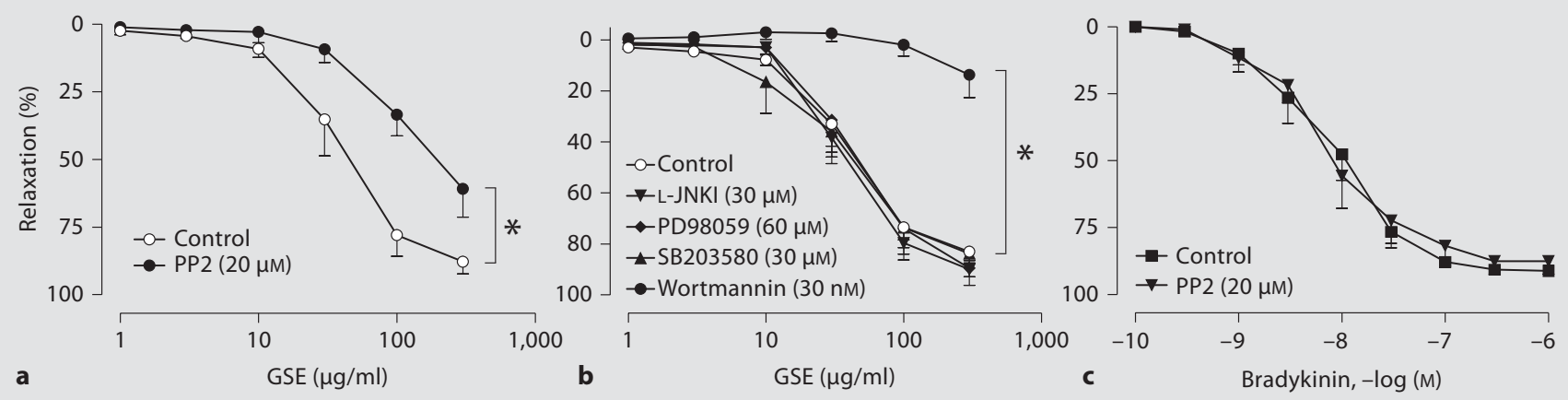

Fig. 4. Role of redox-sensitive protein kinases on endotheliumdependent NO-mediated relaxation to GSE in intact coronary artery rings. Artery rings with endothelium were incubated with either solvent or an inhibitor of Src kinase (PP2; a) and inhibitors of PI3-kinase (wortmannin), ERK1/2 (PD98059), p38 MAPK (SB203580) and JNK (L-JNKI; b) for $30 \mathrm{~min}$ before the addition of
U46619. c Effect of PP2 on bradykinin-induced NO-mediated relaxation in coronary artery rings with endothelium. All experiments were performed in the presence of charybdotoxin (100 nM), apamin $(100 \mathrm{nM})$ and indomethacin $(10 \mu \mathrm{M})$. Results are shown as the means \pm SEM of 6 different experiments. ${ }^{*} \mathrm{p}<0.05$ for inhibitory effect. the role of ROS in GSE-induced NO-mediated relaxations. NO-mediated relaxations to GSE were abolished by the membrane permeable superoxide dismutase mimetic, MnTMPyP, and the membrane permeable catalase, PEG-catalase, whereas native catalase was without effect, and native superoxide dismutase slightly but significantly potentiated relaxations (fig. $2 \mathrm{a}, \mathrm{b}$ ). Relaxations to GSE were not significantly affected by the antioxidant and NADPH oxidase inhibitor apocynin, the xanthine oxidase inhibitor allopurinol, the cytochrome P450 oxidase inhibitor sulfaphenazol and by the mitochondrial chain respiration inhibitor rotenone (fig. 3).

\section{Role of Redox-Sensitive Protein Kinases in}

\section{GSE-Induced NO-Mediated Relaxation}

ROS such as superoxide anions have important signaling function in vascular cells [21]. In particular, numerous protein kinases are redox-sensitive such as mitogenactivated protein kinases (MAPK) p38, extracellular-related kinases 1 and 2 (ERK1/2), c-Jun $\mathrm{N}$-terminal kinase (JNK), Src kinase and phosphoinositide 3-kinase (PI3kinase). Therefore, the role of these redox-sensitive protein kinases in GSE-induced NO-mediated relaxation was clarified. Relaxations to GSE were significantly inhibited by PP2 and wortmannin (inhibitors of Src kinase and PI3-kinase, respectively), whereas they were not affected by L-JNKI (an inhibitor of JNK), PD98059 (an inhibitor of ERK1/2 kinase) and SB203580 (an inhibitor of p38 MAPK) (fig. 4a, b). In contrast to GSE, PP2 did not affect NO-mediated relaxations to bradykinin (fig. 4c). PP2 and wortmannin did not significantly affect the level of contraction induced by U46619 (the values were 17.0 \pm 1.0 and $15.1 \pm 1.2 \mathrm{~g}$ in the absence and presence of $\mathrm{PP} 2$, and $12.6 \pm 1.3$ and $11.2 \pm 1.1 \mathrm{~g}$ in the absence and presence of wortmannin).

\section{GSE Stimulates the Formation of ROS in Cultured and Native Endothelial Cells}

The ability of GSE to stimulate the formation of ROS was examined in cultured coronary artery endothelial cells using DHE staining, and in coronary artery sections using $2^{\prime}, 7^{\prime}$-dichlorodihydrofluorescein diacetate. GSE increased DHE fluorescence in cultured endothelial cells, and MnTMPyP abolished this effect (fig. 5a, b). GSE also consistently increased the low basal fluorescence signal in coronary artery sections with endothelium (fig. 5c). The increased fluorescence signal was predominantly located at the luminal surface of intact sections and also to some extent in the adventitia, whereas no such increase was observed in the vascular smooth muscle (fig. $5 \mathrm{c}$ ). The GSE-increased fluorescence signal in the endothelium was abolished by MnTMPyP (fig. 5d).

\section{GSE Induces a Redox-Sensitive Phosphorylation of \\ Src, Akt and eNOS in Endothelial Cells}

Numerous studies have indicated that the PI3-kinase pathway mediates activation of eNOS through the Aktdependent phosphorylation of eNOS at Ser1177 in re- 


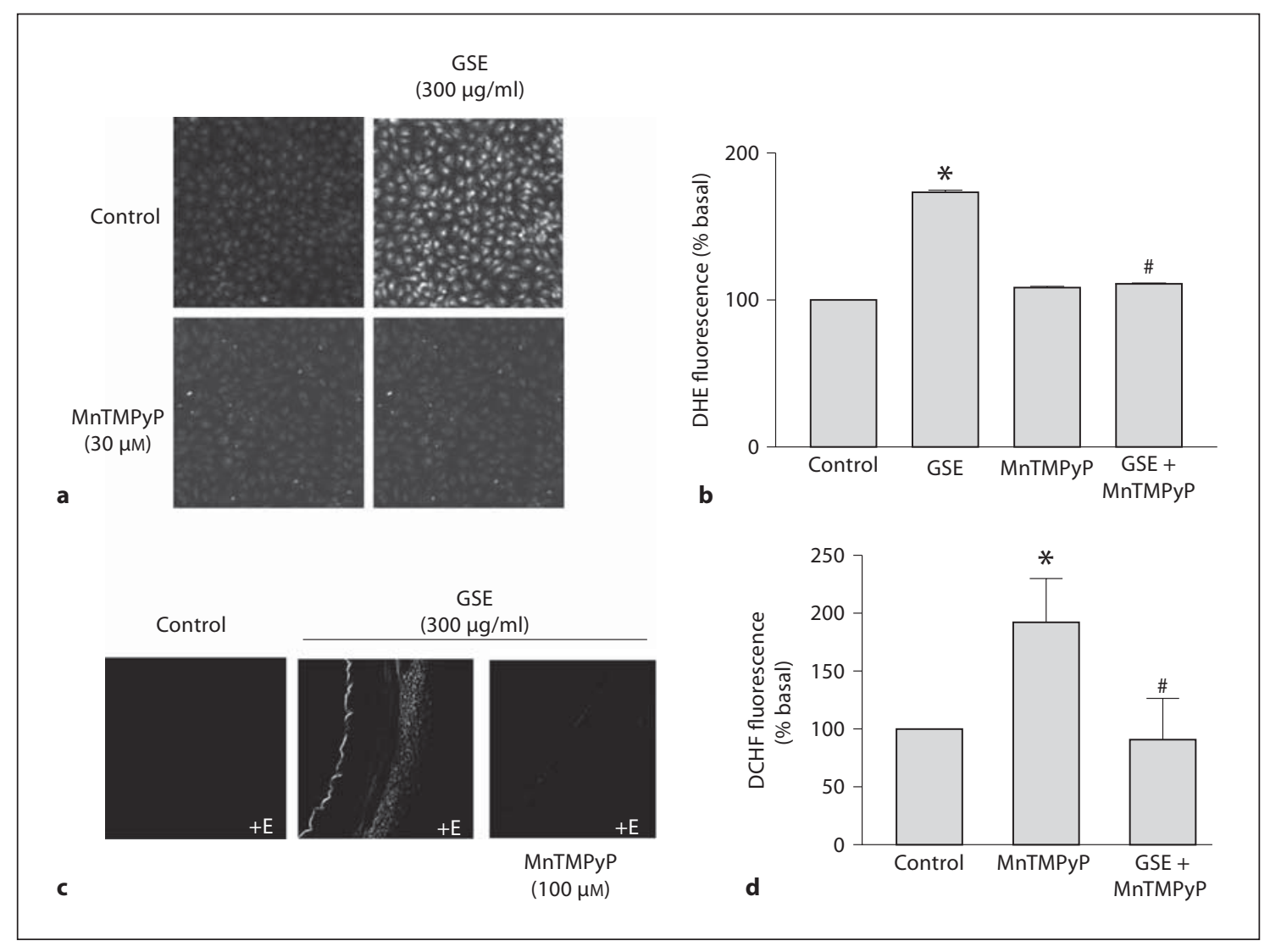

Fig. 5. GSE induces the formation of ROS in cultured and native coronary artery endothelial cells. a, b Cells loaded with $10-\mu \mathrm{M}$ DHE were either untreated or exposed to GSE in the absence and presence of MnTMPyP $(30 \mu \mathrm{M})$ for $30 \mathrm{~min}$. Ethidium bromide fluorescence was monitored over 10 min using a confocal microscope. a Representative original photos. b Cumulative data. Results are shown as the means \pm SEM of 3 or 4 different experiments. ${ }^{*} \mathrm{p}<0.05$ vs. control; ${ }^{*} \mathrm{p}<0.05$ vs. GSE treatment alone. c, d Coronary artery sections with endothelium exposed to $2^{\prime}, 7^{\prime}$ dichlorodihydrofluorescein diacetate $(1 \mu \mathrm{M})$ for $10 \mathrm{~min}$ were treated with either solvent (Control) or GSE (300 $\mu \mathrm{g} / \mathrm{ml}, 10 \mathrm{~min})$ in the absence or presence of MnTMPyP $(100 \mu \mathrm{M})$. c Representative original photos. $\mathbf{d}$ Cumulative data. Results are shown as the means \pm SEM of 3-5 different experiments. ${ }^{*} \mathrm{p}<0.05$ vs. control; ${ }^{\#} \mathrm{p}<0.05$ vs. GSE treatment alone. sponse to several physiological stimuli, including shear stress, estrogens, vascular endothelial growth factor, $\mathrm{H}_{2} \mathrm{O}_{2}$ and high density lipoprotein [22-27]. In order to determine whether such a mechanism is involved in the endothelial formation of NO in response to GSE, the phosphorylation level of Akt and eNOS was determined by immunoblotting. Unstimulated endothelial cells had a low level of phosphorylated Akt at Ser473 (fig. 6a) and of phosphorylated eNOS at Ser1177 (fig. 6b). Exposure of endothelial cells to GSE caused the appearance within 5-10 min of a pronounced phosphorylation of Akt at Ser473 and eNOS at Ser1177. Thereafter, the signal persisted for at least $120 \mathrm{~min}$ for Akt whereas the phosphorylation level of eNOS returned to baseline at $30 \mathrm{~min}$ (fig. 6a, b). In addition, GSE also significantly enhanced the phosphory- lation level of Src in endothelial cells (fig. 7a). GSE-induced phosphorylation of Src, Akt and eNOS was abolished by pretreatment of cells with MnTMPyP and that of Akt end eNOS by PEG-catalase (fig. 7a-c). In addition, inhibition of Src kinase (by PP2) and PI3-kinase (by wortmannin, LY294002) prevented the stimulatory effect of GSE on Akt and eNOS (fig. 8a, b).

\section{Effect of GSE on Endothelial Cell Viability}

The viability of endothelial cells was not affected following exposure to GSE $(300 \mu \mathrm{g} / \mathrm{ml})$ for $30 \mathrm{~min}$, as assessed by CellTiter 96 MDSU Aqueous One Solution cell proliferation assay (Promega, $103.1 \pm 1.4 \%, 2$ different experiments performed in quadruplicate). 


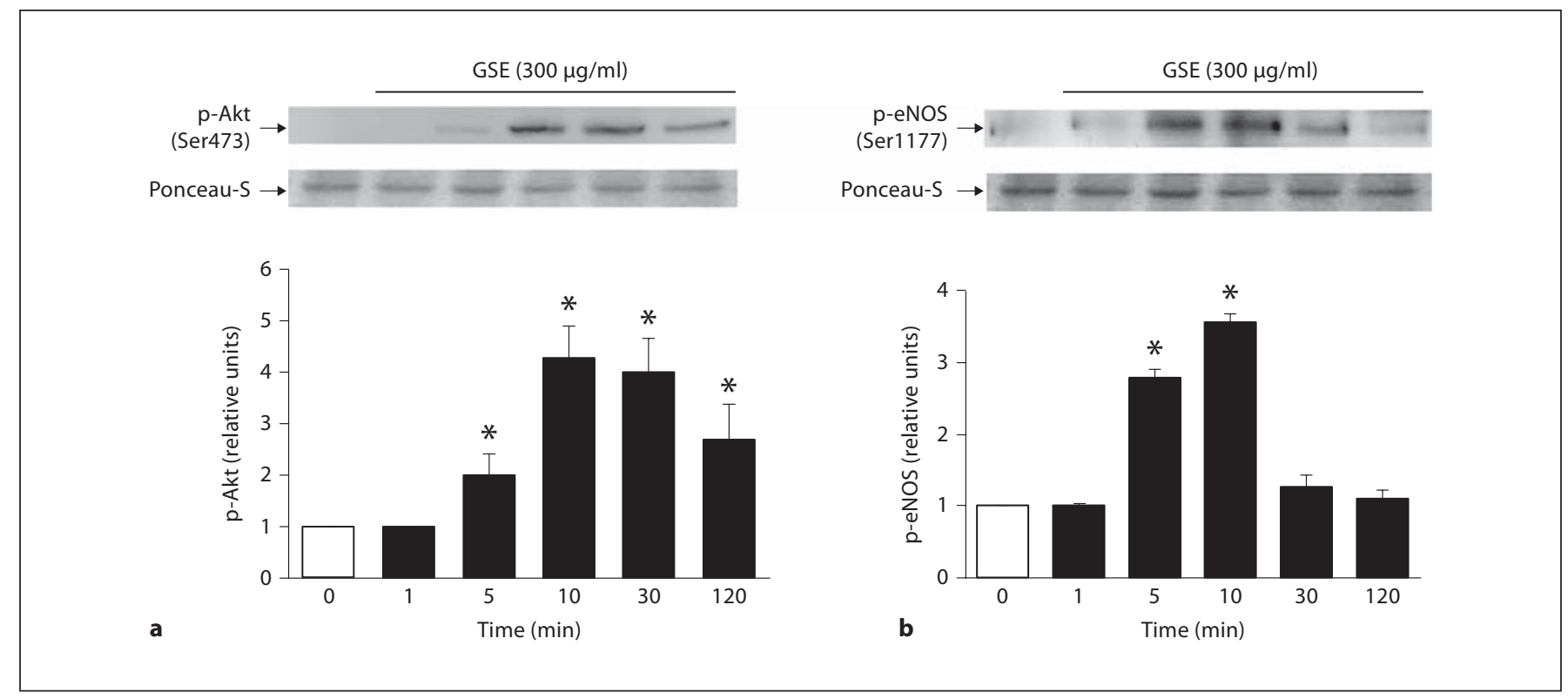

Fig. 6. GSE causes a time-dependent phosphorylation of Akt at Ser473 (a) and eNOS at Ser1177 (b) in cultured porcine coronary artery endothelial cells. All experiments were performed in the presence of charybdotoxin $(100 \mathrm{nM})$, apamin $(100 \mathrm{nM})$ and indomethacin $(10 \mu \mathrm{M})$. Results are shown as the means \pm SEM of 3 different experiments. ${ }^{*} \mathrm{p}<0.05$ for inhibitory effect.

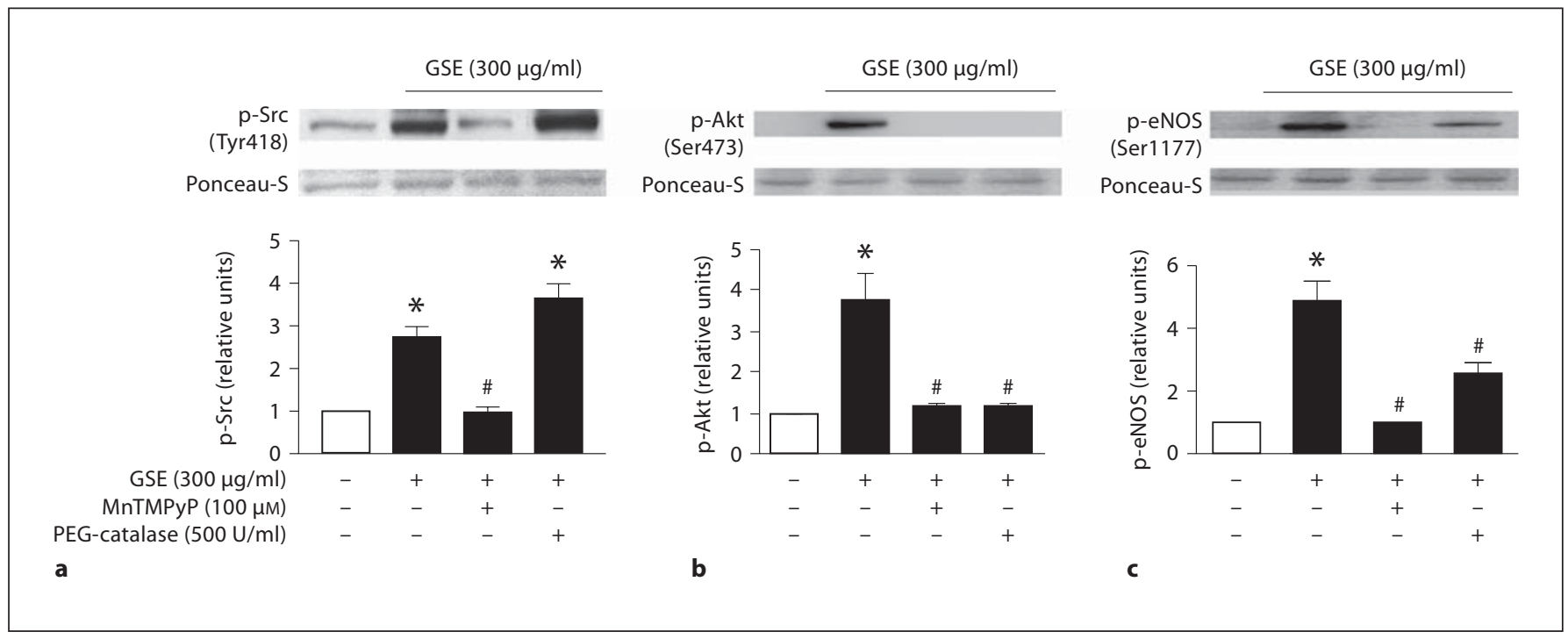

Fig. 7. Role of intracellular ROS on GSE-induced phosphorylation of Src (a), Akt (b) and eNOS (c) in coronary artery endothelial cells. Endothelial cells were exposed either to solvent, MnTMPyP or PEG-catalase for $30 \mathrm{~min}$ before the addition of GSE for $10 \mathrm{~min}$. Thereafter, the level of p-Src, p-Akt and p-eNOS was determined by Western blot analysis. Upper panels show representative im- munoblots and lower panels show the corresponding cumulative data. All experiments were performed in the presence of charybdotoxin (100 nM), apamin (100 nM) and indomethacin (10 $\mu \mathrm{M})$. Results are shown as the means \pm SEM of 3 or 4 different experiments. ${ }^{*} \mathrm{p}<0.05$ vs. control; ${ }^{*} \mathrm{p}<0.05$ vs. GSE treatment alone. 


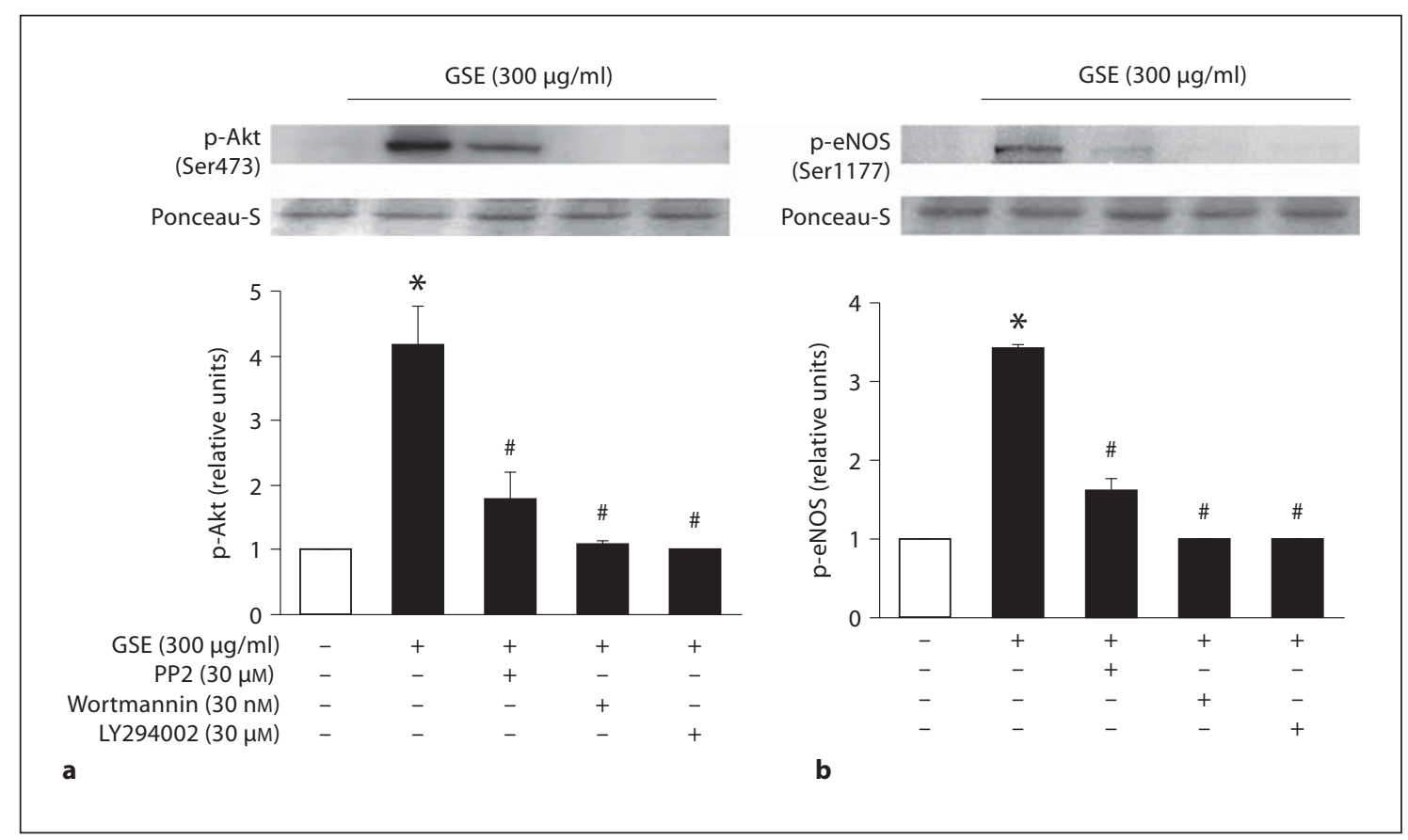

Fig. 8. Role of the redox-sensitive Src kinase and the PI3-kinase/ Akt pathway in GSE-induced phosphorylation of Akt (a) and eNOS (b) in coronary artery endothelial cells. Endothelial cells were either exposed to solvent or PP2, wortmannin and LY294002 for $30 \mathrm{~min}$ before the addition of GSE for $10 \mathrm{~min}$. Thereafter, the level of p-Akt and p-eNOS was determined by Western blot anal- ysis. Upper panels show representative immunoblots and lower panels show the corresponding cumulative data. All experiments were performed in the presence of charybdotoxin (100 nM), apa$\min (100 \mathrm{nM})$ and indomethacin $(10 \mu \mathrm{M})$. Results are shown as the means \pm SEM of 3 or 4 different experiments. ${ }^{*} \mathrm{p}<0.05$ vs. control; ${ }^{\#} \mathrm{p}<0.05$ vs. GSE treatment alone.

\section{Discussion}

The present findings indicate that an alcohol-free polyphenol-rich GSE from V. labrusca induces potent endothelium-dependent relaxations of porcine coronary arteries by increasing the formation of $\mathrm{NO}$ and also, to some extent, EDHF. They further indicate that the GSEinduced formation of $\mathrm{NO}$ is due to the redox-sensitive Src kinase/PI3-kinase/Akt-dependent activation of eNOS by phosphorylation.

GSE caused potent relaxations of intact coronary arteries, but only minor ones in rings without endothelium. The fact that relaxations to GSE were reduced by L-NA and not affected by the combination of charybdotoxin plus apamin indicates a major role for NO. However, since the addition of charybdotoxin plus apamin to L-NA further reduced relaxations to GSE, EDHF is also involved to some extent. The present findings are in agreement with previous ones indicating that GSE caused vasodilatation in the perfused rat mesenteric arterial bed by increasing the formation of $\mathrm{NO}$ and $\operatorname{EDHF}[17,18]$. Be- sides grape skin extracts, other grape-derived products, including red wine, red wine extracts, grape juices and grape seed extracts, have also been shown to cause endothelium-dependent relaxations involving $\mathrm{NO}$ and EDHF $[9,10,13,28,29]$.

The present findings also indicate that GSE is able to cause the intracellular formation of ROS in cultured and native coronary artery endothelial cells, but not in native vascular smooth muscle. Moreover, they further indicate that the GSE-induced formation of ROS is a critical initial event in the signal transduction pathway leading to eNOS activation and subsequent relaxation. Indeed, GSE-induced relaxations were markedly reduced by membrane permeable analogues of superoxide dismutase and catalase, but not by native superoxide dismutase and catalase. Similar findings have been observed with red wine polyphenols and grape juice [12$14,29]$. Although the source of ROS in endothelial cells remains to be determined, endothelium-dependent relaxations to GSE and red wine polyphenols were not affected by inhibitors of xanthine oxidase, NADPH oxi- 
dase, the mitochondrial chain respiration, cytochromes P450 or cyclooxygenases [present findings, 12, 14]. Potential sources include other types of ROS-generating enzymes and the polyphenolic compound itself $[21,30$, 31]. In addition to polyphenols, several physiological activators of eNOS, such as vascular endothelial growth factor, shear stress, and bradykinin, have also been shown to induce the formation of ROS in endothelial cells [32-34].

ROS are now widely recognized as important signaling molecules involved in the physiological control of cell function, in part by the activation of redox-sensitive protein kinases [21]. The present findings indicate a major role of the PI3-kinase/Akt pathway, under the control of ROS, in GSE-induced eNOS activation. Indeed, GSE caused a comparable time course for relaxation and phosphorylation of eNOS and Akt in endothelial cells. In addition, inhibition of the PI3-kinase prevented the GSEinduced phosphorylation of Akt and eNOS and relaxations. In contrast to PI3-kinase, inhibition of other redox-sensitive kinases, such as p38 MAPK, ERK1/2 and JNK, did not affect GSE-induced NO-mediated relaxations. Moreover, NO-mediated relaxations to bradykinin were affected by neither MnTMPyP nor wortmannin [13]. Furthermore, membrane permeable analogues of superoxide dismutase and catalase prevented the phosphorylation of Akt and eNOS in response to GSE. Altogether, these findings indicate that grape-derived polyphenols activate eNOS by using an original signaling pathway involving the redox-sensitive activation of the PI3-kinase/Akt pathway, leading to an enhanced formation of NO following phosphorylation of eNOS. Consistent with such a sequence of events, moderate concentrations of hydrogen peroxide increase the activity of eNOS through the PI3-kinase/Akt-dependent phosphorylation of eNOS at Ser1177 [35, 36].

The present findings also indicate that Src kinase is an upstream mediator of the PI3-kinase/Akt pathway leading to the GSE-induced phosphorylation of eNOS. Indeed, inhibition of Src kinase reduced GSE-induced phosphorylation of Akt and eNOS and relaxations. Moreover, GSE caused the phosphorylation of Src kinase; this response was prevented by the membranepermeable analogue of superoxide dismutase, but not of catalase. These findings indicate that the initial event leading to NO formation in response to GSE is the intracellular formation of ROS. The moderate pro-oxidant signal, involving superoxide anions, triggers the phosphorylation of Src kinase leading to the activation of the PI3-kinase/Akt pathway that ultimately enhances
eNOS activity by phosphorylation. In addition, the moderate pro-oxidant signal might also involve hydrogen peroxide, which in turn acts downstream of Src kinase to activate the PI3-kinase/Akt pathway resulting also in an increased eNOS activity.

Although polyphenols caused a modest pro-oxidant signal in endothelial cells, no such effect has been observed with other types of vascular cells. Indeed, polyphenols did not induce the formation of ROS in the vascular smooth muscle of coronary arteries [present findings] and they prevented growth factor-induced NADPH oxidase-dependent formation of ROS in vascular smooth muscle cells [37]. In addition, grape seed and skin extracts prevented the stimulation-induced release of superoxide anions in platelets [38]. These protective effects of polyphenols might be due to their ability to scavenge superoxide anions, peroxyl radicals, hydroxyl radicals and peroxynitrite [39-41]. In addition, the protective effect might also be due to their ability to prevent the expression of pro-oxidant enzymes, such as NADPH oxidase and xanthine oxidase, and to increase that of antioxidant enzymes such as catalase [42-44]. Indeed, an intake of red wine polyphenols prevented oxidative stress and the endothelial dysfunction in the aorta, which were induced by the infusion of angiotensin II to rats [44].

Altogether, the previous and present findings suggest that the beneficial effect of grape-derived polyphenols on the vascular system might be due to their ability to enhance the redox-sensitive formation of vasoprotective factors in endothelial cells and to prevent oxidative stress in the vascular smooth muscle and platelets.

\section{Acknowledgements}

This study was supported by CAPES (Brazil) and COFECUB (France). 


\section{References}

1 St. Leger AS, Cochrane AL, Moore F: Factors associated with cardiac mortality in developed countries with particular reference to the consumption of wine. Lancet 1979;1: 1017-1020.

$>2$ Renaud SC, Gueguen R, Schenker J, D'houtaud A: Alcohol and mortality in middle-aged men from eastern France. Epidemiology 1998;9:184-188.

-3 Gronbaek M, Becker U, Johansen D, Gottschau A, Schnohr P, Hein HO, Jensen G, Sorensen TI: Type of alcohol consumed and mortality from all causes, coronary heart disease, and cancer. Ann Intern Med 2000; 133:411-419.

4 Stoclet JC, Chataigneau T, Ndiaye M, Oak MH, El Bedoui J, Chataigneau M, SchiniKerth VB: Vascular protection by dietary polyphenols. Eur J Pharmacol 2004;500: 299-313.

$\checkmark 5$ Taubert D, Berkels R, Roesen R, Klaus W: Chocolate and blood pressure in elderly individuals with isolated systolic hypertension. JAMA 2003;290:1029-1030.

6 Heiss C, Dejam A, Kleinbongard P, Schewe T, Sies H, Kelm M: Vascular effects of cocoa rich in flavan-3-ols. JAMA 2003;290:10301031.

-7 Fisher ND, Hughes M, Gerhard-Herman M, Hollenberg NK: Flavanol-rich cocoa induces nitric-oxide-dependent vasodilation in healthy humans. J Hypertens 2003;21:22812286.

-8 Hashimoto M, Kim S, Eto M, Iijima K, Ako J, Yoshizumi M, Akishita M, Kondo K, Itakura H, Hosoda K, Toba K, Ouchi Y: Effect of acute intake of red wine on flow-mediated vasodilatation of the brachial artery. Am J Cardiol 2001;88:1457-1460.

$\checkmark 9$ Fitzpatrick DF, Hirschfield SL, Coffey RG: Endothelium-dependent vasorelaxing activity of wine and other grape products. Am J Physiol 1993;265:H774-H778.

10 Flesch M, Schwarz A, Bohm M: Effects of red and white wine on endothelium-dependent vasorelaxation of rat aorta and human coronary arteries. Am J Physiol 1998;275:H1183H1190.

11 Schini-Kerth VB: Vascular biosynthesis of nitric oxide: effect on hemostasis and fibrinolysis. Transfus Clin Biol 1999;6:355-363.

-12 Ndiaye M, Chataigneau T, Andriantsitohaina R, Stoclet JC, Schini-Kerth VB: Red wine polyphenols cause endothelium-dependent EDHF-mediated relaxations in porcine coronary arteries via a redox-sensitive mechanism. Biochem Biophys Res Commun 2003; 310:371-377.

13 Ndiaye M, Chataigneau T, Chataigneau M, Schini-Kerth VB: Red wine polyphenols induce EDHF-mediated relaxations in porcine coronary arteries through the redox-sensitive activation of the PI3-kinase/Akt pathway. Br J Pharmacol 2004;142:1131-1136.
14 Ndiaye M, Chataigneau M, Lobysheva I, Chataigneau T, Schini-Kerth VB: Red wine polyphenol-induced, endothelium-dependent NO-mediated relaxation is due to the redox-sensitive PI3-kinase/Akt-dependent phosphorylation of endothelial NO-synthase in the isolated porcine coronary artery. FASEB J 2005; 19:455-457.

15 Feletou M, Vanhoutte PM: EDHF: new therapeutic targets? Pharmacol Res 2004;49: 565-580.

$\checkmark 16$ Soares De Moura R, Costa Vieira FS, Souza MAV, Kovary K, Guedes DC, Oliveira EPB, Rubenich LMS, Carvalho LCRM, Tano T, Gusmão Correia ML: Antihypertensive, vasodilator and antioxidant effects of vinifera grape-skin extract. J Pharm Pharmacol 2002; 54:1515-1520.

17 Soares De Moura R, Miranda DZ, Pinto AC, Sicca RF, Souza MA, Rubenich LM, Carvalho LC, Rangel BM, Tano T, Madeira SV, Resende AC: Mechanism of the endothelium-dependent vasodilation and the antihypertensive effect of Brazilian red wine. J Cardiovasc Pharmacol 2004;44:302-309.

18 Madeira SV, De Castro Resende A, Ognibene DT, De Sousa MA, Soares De Moura R: Mechanism of the endothelium-dependent vasodilator effect of an alcohol-free extract obtained from a vinifera grape skin. Pharmacol Res 2005;52:321-327.

19 Singleton VL, Rossi JA: Colorimetry of total phenolics with phosphomolybdic-phosphotungstic acid reagents. Am J Enol Vitic 1965; 16:144-158.

20 Miller FJ Jr, Gutterman DD, Rios CD, Heistad DD, Davidson BL: Superoxide production in vascular smooth muscle contributes to oxidative stress and impaired relaxation in atherosclerosis. Circ Res 1998;82:12981305.

$>21$ Ullrich V, Bachschmid M: Superoxide as a messenger of endothelial function. Biochem Biophys Res Commun 2000;278:1-8.

22 Corson MA, James NL, Latta SE, Nerem RM, Berk BC, Harrison DG: Phosphorylation of endothelial nitric oxide synthase in response to fluid shear stress. Circ Res 1996;79:984991.

23 Garcia-Cardena G, Fan R, Stern DF, Liu J, Sessa WC: Endothelial nitric oxide synthase is regulated by tyrosine phosphorylation and interacts with caveolin-1. J Biol Chem 1996; 271:27237-27240.

24 Michell BJ, Griffiths JE, Mitchelhill KI, Rodriguez-Crespo I, Tiganis T, Bozinovski S, De Montellano PR, Kemp BE, Pearson RB: The Akt kinase signals directly to endothelial nitric oxide synthase. Curr Biol 1999;9: 845-848.
25 Harris MB, Ju H, Venema VJ, Liang H, Zou R, Michell BJ, Chen ZP, Kemp BE, Venema RC: Reciprocal phosphorylation and regulation of endothelial nitric-oxide synthase in response to bradykinin stimulation. J Biol Chem 2001;276:16587-16591.

26 Boo YC, Sorescu G, Boyd N, Shiojima I, Walsh K, Du J, Jo H: Shear stress stimulates phosphorylation of endothelial nitric-oxide synthase at Ser1179 by Akt-independent mechanisms: role of protein kinase A. J Biol Chem 2002;277:3388-3396.

27 Mineo C, Yuhanna IS, Quon MJ, Shaul PW: High density lipoprotein-induced endothelial nitric-oxide synthase activation is mediated by Akt and MAP kinases. J Biol Chem 2003;278:9142-9149.

-28 Andriambeloson E, Kleschyov AL, Muller B, Beretz A, Stoclet JC, Andriantsitohaina R: Nitric oxide production and endotheliumdependent vasorelaxation induced by wine polyphenols in rat aorta. Br J Pharmacol 1997;120:1053-1058.

-29 Anselm E, Chataigneau M, Ndiaye M, Chataigneau T, Schini-Kerth VB: Grape juice causes endothelium-dependent relaxation via a redox-sensitive Src- and Akt-dependent activation of eNOS. Cardiovasc Res 2007;73: 404-413.

30 Roques SC, Landrault N, Teissedre PL, Laurent C, Besancon P, Rouane JM, Caporiccio $\mathrm{B}$ : Hydrogen peroxide generation in caco-2 cell culture medium by addition of phenolic compounds: effect of ascorbic acid. Free Radic Res 2002;36:593-599.

>31 Long LH, Clement MV, Halliwell B: Artifacts in cell culture: rapid generation of hydrogen peroxide on addition of (-)-epigallocatechin, (-)-epigallocatechin gallate, (+)-catechin, and quercetin to commonly used cell culture media. Biochem Biophys Res Commun 2000; 273:50-53.

32 Yeh LH, Park YJ, Hansalia RJ, Ahmed IS, Deshpande SS, Goldschmidt-Clermont PJ, Irani K, Alevriadou BR: Shear-induced tyrosine phosphorylation in endothelial cells requires Rac1-dependent production of ROS. Am J Physiol 1999;276:C838-C847.

33 Colavitti R, Pani G, Bedogni B, Anzevino R, Borrello S, Waltenberger J, Galeotti T: Reactive oxygen species as downstream mediators of angiogenic signaling by vascular endothelial growth factor receptor-2/KDR. J Biol Chem 2002;277:3101-3108.

34 Oldenburg O, Qin Q, Krieg T, Yang X, Philipp S, Critz SD, Cohen MV, Downey JM: Bradykinin induces mitochondrial ROS generation via NO, cGMP, PKG, and mitoK $_{\mathrm{ATP}}$ channel opening and leads to cardioprotection. Am J Physiol Heart Circ Physiol 2004; 286:H468-H476. 
>35 Thomas SR, Chen K, Keaney JF Jr: Hydrogen peroxide activates endothelial nitric-oxide synthase through coordinated phosphorylation and dephosphorylation via a phosphoinositide 3-kinase-dependent signaling pathway. J Biol Chem 2002;277:6017-6024.

>36 Cai H, Li Z, Davis ME, Kanner W, Harrison DG, Dudley SC Jr: Akt dependent phosphorylation of serine 1179 and mitogen-activated protein kinase kinase/extracellular signalregulated kinase $1 / 2$ cooperatively mediate activation of the endothelial nitric-oxide synthase by hydrogen peroxide. Mol Pharmacol 2003;63:325-331.

37 Oak MH, Chataigneau M, Keravis T, Chataigneau T, Beretz A, Andriantsitohaina R, Stoclet JC, Chang SJ, Schini-Kerth VB: Red wine polyphenolic compounds inhibit vascular endothelial growth factor expression in vascular smooth muscle cells by preventing the activation of the p38 mitogen-activated protein kinase pathway. Arterioscler Thromb Vasc Biol 2003;23:1001-1007.
38 Vitseva O, Varghese S, Chakrabarti S, Folts JD, Freedman JE: Grape seed and skin extracts inhibit platelet function and release of reactive oxygen intermediates. J Cardiovasc Pharmacol 2005;46:445-451.

$39 \mathrm{Hu}$ JP, Calomme M, Lasure A, De Bruyne T, Pieters L, Vlietinck A, Vanden Berghe DA: Structure-activity relationship of flavonoids with superoxide scavenging activity. Biol Trace Elem Res 1995;47:327-331.

40 Sato M, Maulik G, Ray PS, Bagchi D, Das DK: Cardioprotective effects of grape seed proanthocyanidin against ischemic reperfusion injury. J Mol Cell Cardiol 1999;31:12891297.

41 Aldini G, Carini M, Piccoli A, Rossoni G, Facino RM: Procyanidins from grape seeds protect endothelial cells from peroxynitrite damage and enhance endothelium-dependent relaxation in human artery: new evidences for cardio-protection. Life Sci 2003; 73:2883-2898.
42 Ying CJ, Xu JW, Ikeda K, Takahashi K, Nara Y, Yamori Y: Tea polyphenols regulate nicotinamide adenine dinucleotide phosphate oxidase subunit expression and ameliorate angiotensin II-induced hyperpermeability in endothelial cells. Hypertens Res 2003;26: 823-828.

43 Lin JK, Chen PC, Ho CT, Lin-Shiau SY: Inhibition of xanthine oxidase and suppression of intracellular reactive oxygen species in HL-60 cells by theaflavin-3,3'-digallate, (-)-epigallocatechin-3-gallate, and propyl gallate. J Agric Food Chem 2000;48:27362743.

-44 Sarr M, Chataigneau M, Martins S, Schott C, El Bedoui J, Oak MH, Muller B, Chataigneau T, Schini-Kerth VB: Red wine polyphenols prevent angiotensin II-induced hypertension and endothelial dysfunction in rats: role of NADPH oxidase. Cardiovasc Res 2006;71: 794-802. 